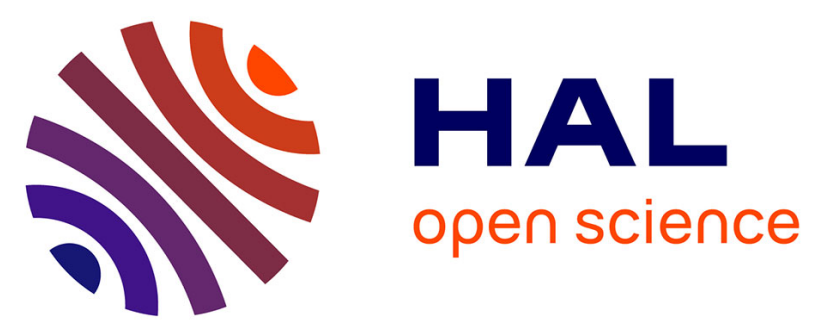

\title{
New trends in Multihazards Probabilistic Safety Assessment for nuclear installations: the H2020-NARSIS Project
}

Evelyne Foerster, Behrooz Bazargan-Sabet, James Daniell, Pierre Gehl, Philip

J. Vardon, Varenya K. Duvvuru Mohan, Giuseppe Rastiello, Luka Štrubelj, Florence Ragon

\section{To cite this version:}

Evelyne Foerster, Behrooz Bazargan-Sabet, James Daniell, Pierre Gehl, Philip J. Vardon, et al.. New trends in Multihazards Probabilistic Safety Assessment for nuclear installations: the H2020-NARSIS Project. EGU General Assembly 2020, May 2020, Vienne, Austria. 10.5194/egusphere-egu2020-5860 . cea-02572415

\section{HAL Id: cea-02572415 https://hal-cea.archives-ouvertes.fr/cea-02572415}

Submitted on 13 May 2020

HAL is a multi-disciplinary open access archive for the deposit and dissemination of scientific research documents, whether they are published or not. The documents may come from teaching and research institutions in France or abroad, or from public or private research centers.
L'archive ouverte pluridisciplinaire $\mathbf{H A L}$, est destinée au dépôt et à la diffusion de documents scientifiques de niveau recherche, publiés ou non, émanant des établissements d'enseignement et de recherche français ou étrangers, des laboratoires publics ou privés. 
EGU2020-5860

https://doi.org/10.5194/egusphere-egu2020-5860

EGU General Assembly 2020

(c) Author(s) 2020. This work is distributed under

the Creative Commons Attribution 4.0 License.

\title{
New trends in Multihazards Probabilistic Safety Assessment for nuclear installations: the H2020-NARSIS Project
}

\author{
Evelyne Foerster ${ }^{1}$, Behrooz Bazargan-Sabet ${ }^{2}$, James Daniell ${ }^{3}$, Pierre Gehl ${ }^{2}$, Philip J. Vardon ${ }^{4}$, \\ Varenya K. Duvvuru Mohan ${ }^{4}$, Giuseppe Rastiello ${ }^{1}$, Luka Štrubelj ${ }^{5}$, and Florence Ragon ${ }^{1}$ \\ ${ }^{1}$ DEN - Mechanics \& Thermal Study Unit, CEA, Paris-Saclay University, 91191, Gif-sur-Yvette, France

The methodology for Probabilistic Safety Assessment (PSA) of Nuclear Power Plants (NPPs) has been used for decades by practitioners to better understand the most probable initiators of nuclear accidents by identifying potential accident scenarios, their consequences, and their probabilities. However, despite the remarkable reliability of the methodology, the Fukushima Daiichi nuclear accident in Japan, which occurred in March 2011, highlighted a number of challenging issues (e.g. cascading event - cliff edge - scenarios) with respect to the application of PSA questioning the relevance of PSA practice, for such low-probability but high-consequences external events. Following the Fukushima Dai-ichi accident, several initiatives at the international level, have been launched in order to review current practices and identify shortcomings in scientific and technical approaches for the characterization of external natural extreme events and the evaluation of their consequences on the safety of nuclear facilities.

The H2020 project "New Approach to Reactor Safety ImprovementS" (NARSIS, 2017-2021) aims at proposing some improvements to be integrated in existing PSA procedures for NPPs, considering single, cascade and combined external natural hazards (earthquakes, flooding, extreme weather, tsunamis). It coordinates the research efforts of eighteen partners encompassing leading universities, research institutes, technical support organizations (TSO), nuclear power producers and suppliers, reactor designers and operators from ten countries.

The project will lead to the release of various tools together with recommendations and guidelines for use in nuclear safety assessment, including a Bayesian-based multi-risk framework able to account for causes and consequences of technical, social/organizational and human aspects and as well as a supporting Severe Accident Management decision-making tool for demonstration purposes.

The NARSIS project has now been running for two years and a half, and the first set of deliverables and tools have been produced as part of the effort of the consortium. Datasets have been 
collected, methodologies tested, states of the art have been produced, and various criteria and plans developed. First results have started to emerge and will be presented here. 